\title{
IN MEMORIAM JÜRI ANT (1939-2020)
}

Tänavu 15. veebruaril lahkus manalateele väljapaistev ajaloolane ja õppejõud Jüri Ant - kolm kuud pärast oma armastatud abikaasat Veera Anti.

Nende mõlema töine elu oli seotud Tartu Ülikooliga. Veera oli kauaaegne ülikooli teenistuja, kes töötas ka ülikooli teadussekretäri vastutusrikkas ametis. Jüri õppejõutöö vältas neli kümnendit, sellest 20 aastat töötas ta professorina. Tegelikult jätkus see veel hulk aastaid pärast emeriteerumist.

Teadlasena oli Jüri Ant üks kaalukamaid Eesti esimese omariiklusaja poliitilise ajaloo uurijaid. Loomulikult on ta olnud ka väga paljude ajaloolaste õpetaja. Kuid Jüri Andi tegevus ei jäänud kitsalt ülikooli seinte vahele: Eesti taasiseseisvumisel andis ta oma panuse ka ajalooteaduse populariseerimisse ja kooliõpikute koostamisse.

Jüri Ant sündis vahetult enne Teise maailmasõja algust, 4. augustil 1939 Tartus Martin ja Leonore Andi peres. Pärast Tartu 5. Keskkooli (tänase Tamme Gümnaasiumi) lõpetamist sai temast 1958. aastal ülikooli ajalooosakonna üliõpilane. Tavapärase stuudiumi kõrval lõi ta kaasa ajalooringis ning kirjutas auhinnatud uurimistöid. 1963. aastal sai temast NLKP ajaloo õppekabineti juhataja. 1964. aastal jätkas ta õpinguid aspirantuuris.

Nii Andi diplomi- kui ka kandidaaditöö käsitlesid 1920. aastate töölisajakirjandust Eestis. Mõlema juhendajaks oli Abe Liebman. 1939. aastal Tartu Ülikooli lõpetanud, 1951. aastal puhastuse alla langenud ja 1956. aastast Eestimaa Kommunistliku Partei Keskkomitee Partei Ajaloo Instituudi vanemteadurina töötanud Liebman oli samuti keskendunud sõdadevahelise Eesti Vabariigi vasakliikumise uurimisele.

See oli ametlikult soositud uurimissuund, kuid selle kaudu oli võimalik tegeleda ka põlualuse "kodanliku Eesti" ajalooga ja pääseda ligi sellega seotud allikmaterjalile. Meenutagem, et Tartu Ülikoolis puudus sel ajal isegi Eesti ajaloole keskendunud professuur. Eesti ajaloo kateeder oli 1949. aastal liidetud NSV Liidu ajaloo kateedriga. Sula-aeg oli siiski ühiskonnateaduste olukorda veidi leevendanud. Aastal 1969 kaitstud väitekirja "Legaalne revolutsiooniline töölisajakirjandus Eestis aastail 1926-1930" põhjal ilmus 
monograafia "Sõjariist kodanluse vastu. Legaalne revolutsiooniline töölisajakirjandus Eestis aastail 1926-1930" (1975).

Aastatel 1969-83 töötas Jüri Ant Tartu Ülikooli NLKP ajaloo kateedris õppejõuna. Tegu oli ühega neljast ülikoolis üldkohustuslikku "punast" eriala õpetavast kateedrist. Need kateedrid olid väljaspool teaduskondi. Jüri Ant jätkas seal uurimistööga ning väitles end aastal 1982 ajaloodoktoriks dissertatsiooniga "Eestimaa Kommunistlik Partei võitluses töörahva ülddemokraatlike nõudmiste eest 1920-1940-ndatel aastatel”(“Коммунистическая партия Эстонии в борьбе за общедемократичекие требования трудового народа в 1920-1940 гг").

Aastal 1983 lahkus Jüri Ant NLKP ajaloo kateedrist ja sai ajalooteaduskonna ajaloo-osakonna NSV Liidu ajaloo kateedri professoriks. See oli üks tollase osakonna kahest kateedrist (teine oli üldajaloo kateeder). Kindlasti olnuks parteiajaloolasena lihtsam karjääri teha, aga ilmselt sealsed raamid ja õhkkond ei sobinud talle. Ant jätkas professori ja kateedrijuhataja tööd kuni emeriteerumiseni 2004. aastal. Kateeder vahetas nimesid ning sellest sai tükiks ajaks lähiajaloo õppetool - praeguse Tartu Ülikooli ajaloo ja arheoloogia instituudi uusima aja osakonna eelkäija.

1980. aastate teisel poolel kärises nõukogude režiim kõigist õmblustest ning ajalooteadus vabanes kammitsatest. Sellist ühiskondlikku tähelepanu ei ole ajaloolased Eestis saanud varem ega hiljem. Pool sajandit kehtinud punased müüdid vajasid kummutamist ja valged laigud täitmist. Aktiivselt lõi selles kaasa ka Jüri Ant: teaduskonverentsidel esineja, dokumendikogumike koostaja, artiklite autori ja ka ajalehepoleemikas nõukoguliku ajalookäsitluse kriitikuna. Samuti osales ta 1989. aastal Eesti NSV Ülemnõukogu Presiidiumi moodustatud komisjonis, mille eesmärk oli 1940. aastal Eestis toimunud sündmuste ajaloolis-õigusliku hinnangu väljatöötamine. Komisjoni uurimistöö tulemus oli ühene: Eestis oli toimunud nõukogude agressioon, okupatsioon ja anneksioon. Taustaks tuleks meenutada, et 1988. aastal ei olnud sündmuste võimalik areng sugugi selge ning punane tagurlus üritas veel korduvalt asuda n-ö kruve taas kinni keerama. Jüri Ant andis aga oma meelsusest selgelt teada - muuhulgas ühinedes ajalehes Edasi ilmunud avaliku kirjaga, milles vastustati Eesti NSV tollase tippjuhtkonna katset õigustada küüditamist.

Taasiseseisvuvas ja taasiseseisvunud Eestis oli terav puudus ajalooalasest õppekirjandusest. Jüri Ant osales mitme kooliõpiku koostamises alates 1989. aastal ilmunud õpikust "Eesti ajalugu: konspektiivne õppematerjal keskkoolile" ning lõpetades õpperaamatuga "Lähiajalugu: õpik XII klassile" (2000, 2003). 


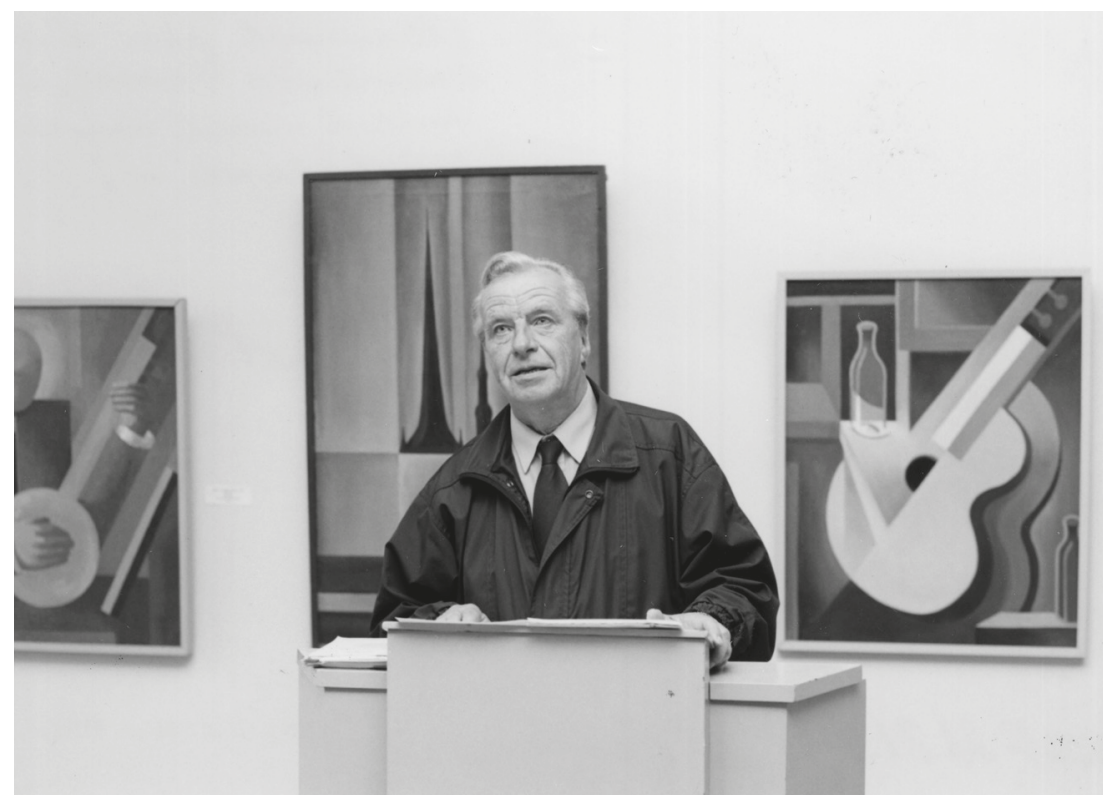

Joonis 1. Jüri Ant esitlemas monograafiat August Reist (2012). Allikas: Valitsuse kommunikatsioonibüroo

1980. aastate lõpul ja 1990. aastate algul, mil avanes palju uusi võimalusi, kaugenesid paljud ajalooharidusega inimesed senisest erialast. Jüri Ant jäi aga kindlalt akadeemiliseks ajaloolaseks. Palju tähelepanu sai nii ajaloolaste kui ka laiema avalikkuse seas tema raamat "Eesti 1920: iseseisvuse esimene rahuaasta" (1990). Ta on ka mitme Eesti ajalugu käsitleva teose kaasautor: "Eesti ajalugu ärkamisajast kuni tänapäevani" (1992), "Eesti ajalugu VI. Vabadussõjast taasiseseisvumiseni” (2005), “Sõja ja rahu vahel II. Esimene punane aasta. Okupeeritud Eesti julgeolekupoliitiline olukord sõja alguseni” (2010). Oma varasemad käsitlused esimese omariikluse lõpust ja okupatsiooni algusest võttis ta 1999. aastal kokku monograafiasse "Eesti 1939-1941: Rahvast, valitsemisest, saatusest”. Jüri Andi viimane monograafia on 2012. aastal ilmunud uurimus "August Rei - Eesti riigimees, poliitik, diplomaat".

Jüri Ant oli Eesti vanima teadusliku ühingu, Õpetatud Eesti Seltsi taasasutajaid (1988) ning 2018. aastast selle auliige. Tema uurimusi ilmus nii seltsi aastaraamatute sarjas ("Asutav Kogu Eesti Vabariigi ajaloos", "Isamaaliit rahva poliitilistest hoiakutest 1939. a kevadel") kui ka paljudes teistes väljaannetes: Tartu Ülikooli ajaloo-ajakirjas Kleio ja sellele järgnenud 
Ajaloolises Ajakirjas, Tunas, Tartu Ülikooli Ajaloo Küsimustes, Eesti Teaduste Akadeemia Toimetistes, Riigikogu Toimetistes, Akadeemias ja Vikerkaares.

Kõige põhjalikum ülevaade Jüri Andist endast on ilmunud Ago Pajuri sulest: "Jüri Ant - 80" (Tuna 3/2019). Tegu on allikmaterjalile tugineva ning ajastulist tausta avava biograafiaga autorilt, kellele Ant oli kolmekordne juhendaja - diplomitööst doktoritööni.

Aga milline oli Jüri Ant inimesena? Ka minul oli võimalus temaga lähemalt kokku puutuda, sh kolm korda juhendatavana: Jüri Ant oli mu diplomi- ja magistritöö juhendaja ning doktoritöö kaasjuhendaja. Heatahtlikkus, kannatlikkus ja muhe huumor on esimesed inimlikud omadused, mis talle mõeldes meelestuvad.

Poolteist aastat tagasi läbisin juhtimistreeningu (executive coaching) kursuse. Mitme kuu vältel õpetati tehnikaid, kuidas suunata inimest ennast lahendusi leidma, kuidas end talle mitte peale suruda ega võtta tema käest vastutust, aga siiski hoida tõhusalt kogu protsessi otstarbekohasuse raamides. Kursuse ajal meenus mu akadeemiline juhendaja mulle korduvalt. Jüri Andi juhendamisviis oli äratuntavalt coaching. Seda nii siis, kui juhendatav alles kobas valitud teel ega julgenud samme seada, kui ka siis, kui juhendatava liigse enesekindluse ja teadmiste-kogemuste vähesuse koosmõju oleks teemakäsitluse kraavi ajanud.

Ajaloo-osakond oli tugeva rahvusliku meelsusega ning kindlasti vaadati Anti tema NLKP ajaloo kateedri taaga pärast pisut kahtlustavalt. Üks mu kooliaegne ajalooõpetaja meenutas mulle tollal oma õpinguajast, kuidas nad olid esitanud punase diktatuuri ilustamise kohta küsimusi ning Ant oli seletanud, et tegelikult olid asjad veel palju hullemad, kui üliópilased ette kujutasid.

Osutub, et sellisena mäletavad teda teisedki. Tänavu, kolm aastakümmet hiljem, lugesin tagantjärele ühismeediast Jüri Andi lahkumisteadet ning leidsin sellise sissekande T.S.-lt: "Lisaks ka hea meenutus ülikooliajast, kui ta meile NLKP ajaloo seminare andis, aastatel 1968-1969. Olime kõik kanget vastalisust täis ja püüdsime ikka vastu vaielda sellele, mida õpikutes ja loengutes oli räägitud. Ant kuulas meid alati rahulikult ära ja seejärel selgitas ja tõi näiteid, kuidas tegelikult olid asjad veel palju hullemad kui oleksime osanud arvatagi." 
Kui nüüd püüda Jüri Andi akadeemilist elu hästi lühidalt kokku võtta, siis tal oli kaks liikumapanevat jõudu. Üks oli teaduslik uudishimu. Jüri Ant oli tõeline teadlane, keda kannustas soov uurida ja avastada. Teiseks innustas teda eriti just Eesti esimese omariiklusaja poliitiline ajalugu, mida ta uuris kogu oma akadeemilise tee vältel.

Tulemuseks on mahukas pärand nii erialaselt kaalukate kirjutiste kui ka arvukate tänulike õpilaste näol. Mida paremat võikski soovida inimesele, kes oli hingelt ajaloolane?

Viljar Peep 